\title{
PENGARUH EVALUASI JABATAN TERHADAP PRODUKTIVITAS KINERJA KARYAWAN PADA PERUM BULOG DIVISI REGIONAL NUSA TENGGARA BARAT
}

\author{
Risma $^{1}$, Kukuh Tondoyekti ${ }^{2}$ \\ ${ }^{1}$ Administrasi Bisnis Universitas Muhammadiyah Mataram
}

\begin{abstract}
ABSTRAK
Penelitian ini bertujuan untuk untuk mengetahui ada atau tidak pengaruh evaluasi kerja karyawan terhadap kinerja karyawan di Perum Bulog Divre Nusa Tenggara Barat..Metode penelitian ini menggunakan metode kuantitatif. Penelitian dengan memperoleh data yang berbentuk angka. Penelitian ini mengunakan jenis data primer dan data sekunder. Metode sampling indicator yang dikaji Pengaruh Evaluasi Jabatan Terhadap Produktivitas Kinerja Karyawan Pada Perum Bulog Divisi Regional Nusa Tenggara Barat. Teknikanalisis data Uji Validitas, Uji Reabilitas, Analisa Regresi Linear, Uji HipotesisdanUji R Square/Detreminasi $\left(\mathrm{R}^{2}\right)$

Hasil dari penelitian ini Berdasarkan hasil penelitian maka dapat disimpulkan bahwa evaluasi jabatan berpengaruh signifikan terhadap produktivitas kinerja karyawan pada Perum Bulog Divisi Regionel Nusa Tenggara Barat. Artinya adanya peningkatan evaluasi jabatan menurut karyawan akan meningkatkan produktivitas kerja karyawan. Bobot pengaruh variable evaluasi jabatan terhadap produktivitas kinerja karyawan sebesar 0,984 yang menunjukkan bahwa jika variabele valuasi jabatan menurut responden mengalami kenaikan sebesar 1 satuan variable produktivitas kerja akan mengalami kenaikan sebesar 0,984 .
\end{abstract}

Kata Kunci: Pengaruh, Evaluasi dan Produktivitas Kinerja Karyawan

\section{PENDAHULUAN}

\subsection{Latar Belakang}

Salah satu faktor penentu keberhasilan perusahaan adalah kinerja dan produktivitas karyawan. Setiap organisasi atau intansi dalam melaksanakan program yang diarahkan selalu berdaya guna untuk mencapai tujuan perusahaan. Salah satu caranya adalah meningkatkan kinerja karyawan. Strategi (strategy) adalah kerangka acuan yang terintegasi dan komprehensif yang mengarahkan pilihan-pilihan yang menentukan bentuk dan arah ativitas-aktivitas organisasi menuju pencapaian tujuan-tujuannya (Henry Simamora, 1997:38).

Sedangkan pengertian kinerja (prestasi kerja) merupakan hasil kerja secara kualitas dan kuantitas yang dicapai oleh seorang karyawan dalam melaksanakan tugasnya sesuai dengan tanggung jawab yang diberikan
kepadanya(Mangkunegara, 2005:67). Kinerja pada dasarnya adalah apa yang dilakukan atau tidak dilakukan karyawan sehingga pada akhirnya mempengaruhi seberapa banyak mereka memberi kontribusi kepada instansi atau organisasi termasuk pelayanan kualitas yang disajikan. Strategi peningkatan kinerja adalah cara perusahaan untuk meningkatkan kinerja karyawan agar tujuan perusahaan dapat tercapai. Agar strategi peningkatan kinerja tersebut dapat berhasil maka perusahaan perlu mengetahui sasaran kinerja yang menetapkan adalah individu secara spesifik, dalam bidang proyek, proses, kegiatan rutin dan inti yang akan menjadi tanggung jawab

karyawan. Jika sasaran kinerja ditimbulkan dari dalam diri karyawan akan membentuk suatu kekuatan diri dan jika situasi lingkungan kerja turut menunjang maka pencapaian kinerja akan lebih mudah (Anwar Prabu Mangkunegara, 2005:68). 
Suatu perusahaan, umumnya, pengembangan level organisasi disatukan dalam bagian strategi pengembangan sumber daya manusia. Sumber daya manusia atau sering disebut sebagai karyawan merupakan salah satu unsur yang memegang peranan penting dalam suatu perusahaan. Saat ini sumber manusia tidak lagi dianggap sebagai biaya, tapi dianggap sebagai asset (karyawan). Pengaruh dari sumber daya manusia sangat tergantung dari manajemen perusahaan, oleh karena itu sumber daya manusia harus mendapatkan perhatian yang lebih dari perusahaan, agar tujuan perusahaan dapet tercapai. Perubahaan pada sumber daya manusia ini tidak mudah, tapi harus melalui proses, sedangkan pelatihan karyawan, dilakukan sebagai pollow up dari penilaian kinerja karyawan, dan dilakukan setelah diketahui pencapai kinerja karyawan dan pada bagian kompetensi mana yang perlu dilakukan pelatihan untuk meningkatkan kinerja karyawan tersebut. Adanya perubahan lingkungan organisasi yang semakin kompleks dan kompetitif, mensyaratkan perusahaan untuk bersikap lebih responsip agar tetap bertahan, dalam perubahan perusahaan baik yang terencana maupun tidak terencana, aspek yang terpenting adalah perubahan sumberdaya manusia. Perubahan pada sumber daya manusia ini tidak mudah, tetapi harus melalui proses, sedangkan pelatihan karyawan, dilakukan sebagai follow up dari penilaian kinerja karyawan, dan dilakukan setelah diketahui pencapaian kinerja karyawan dan pada bagian kompetensi mana yang perlu dilakukan pelatihan untuk meningkatkan kinerja karyawan tersebut.

Evaluasi itu sendiri merupakan proses menentukan nilai untuk suatu hal atau objek yang berdasarkan pada acuan acuan tertentu untuk menentukan tujuan tertentu.Dalam perusahaan ,evaluasi dapat diartikan sebagai proses pengukuran akan evektivitas strategi yang digunakan dalam upanya mencapai tujuan perusahaan. Mengembangkan konsep dan mengadakan penelitian awal. Konsep perlu dilaksanakan secara matang sebelum diadakan eksekusi pesan dan perlu diadakan uji coba untuk mengecek kesesuaian antara draf yang dibuat dengan eksekusi pesannya. Dengan uji coba yang dilakukan, pengevaluasi mencoba mencari tanggapan dari khalayak. Tanggapan dari khalayak ini penting untuk mengukur efektifitas pesan yang disampaikan.

Menurut Arikunto, Jabar dan Abdul (2010: 56), evaluasi dipandang sebagai sebuah proses menentukan hasil yang telah dicapai dalam beberapa kegiatan yang direncanakan untuk mendukung tercapainya tujuan. Adanya evaluasi kerja karyawan berarti karyawan mendapatkan perhatian dari atasan, sehingga mendorong karyawan bersemangat untuk bekerja. Hal itu akan terjadi bila proses evaluasi kinerja karyawan dilakukan secara jujur, objektif, dan ada tindak lanjutnya. Tindak lanjut evaluasi karyawan ini akan memberikan kesempatan kepada para karyawan untuk mendaptkan kesemptan promosi, demosi, pengembangan karier, dan kenaikan gaji. Adanya promosi dan kenaikan gaji akan dapat meningkatkan kesejahteraan hidup karyawan dan akan berakibat pada peningkatan motivasi kerja karyawan.

Evaluasi kerja juga dilakukan oleh Perum Bulog Divre Nusa Tenggara Barat untuk meningkatkan produktifitas kinerja karyawan dan mencari kendala-kendala yang dihadapi oleh para karyawan, disamping itu evaluasi kinerja juga dilakukan sebagai pengambilan keputusan memberikan promosi kepada pegawai ternilai yang kinerjanya memenuhi ketentuan pemberian promosi.

Produktivitas kerja adalah kemampuan karyawan dalam berproduksi dibandingkan dengan input yang digunakan, seorang karyawan dapat dikatakan produktif apabila mampu menghasilkan barang atau jasa sesuai dengan diharapkan dalam waktu yang singkat. Selain bahan baku dan tenaga kerja yang harus ada juga faktor-faktor yang mempengaruhi produktivitas kerja yaitu keterampilan, sikap dan etika kerja, tingkat penghasilan, hubungan individu, motivasi (Ravianto, 1985: 139).

Menurut Noe (2010: 351), pelatihan adalah upaya yang direncanakan untuk mempermudah pembelajaran para karyawan tentang pengetahuan, keterampilan, dan perilaku yang berkaitan dengan pekerjaan.

Faktor kritis yang berkaitan dengan keberhasilan jangka panjang organisasi adalah bagai mana kemampuan perusahaan mengukur seberapa baik karyawan bekerja dan menggunakan informasi. Penilaian kerja dapat membantu menumbuhkan motipasi dan peningkatan mutu karyawan, maka dukungan dari atasan dan semua pihak sangat diperlukan agar lebih efektif.

Menurut Bangun (2012: 201), kinerja adalah hasil pekerjaan yang dicapai karyawan bersasarkan persyaratan - persyaratan pekerjaan (Job Requirement) job requirement adalah dipersyaratkan oleh perusahaan untuk mencari dan menyaring kandidat yang memiliki 
kemampuan dan kompetensi untuk melaksanakan pekerjaan dengan baik, sesuai dengan posisi atau jabatan yang dilakukan tersebut.

Menurut Noe (2010: 452), penilaiaan kinerja adalah peroses dimana organisasi mendapatkan impormasi seberapa baik karyawan melakukan pekerjaannya. Menurut Gomes (1995: 195), mengemukakan definisi kinerja karyawan sebagai ungkapan seperti ouput, efisiensi serta efektivitas sering dihubungkan produktivitas.

Berdasarkan pendapat diatas dapat disimpulkan bahwa kinerja karyawan adalah hasil kerja yang dicapai seseorang karyawan, sesuai dengan wewenang atau tanggung jawap masing-masing karyawan selama periode waktu tertentu.

Berdasarkan latar belakang yang dikemukakan diatas, sehingga peneliti mengambil judul "PENGARUH EVALUASI JABATAN TERHADAP PRODUKTIVITAS KINERJA KARYAWAN PADA PERUM BULOG".

\subsection{Rumusan Masalah}

Sebagai mana telah tertuang dalam latar belakang, maka dalam hal ini peneliti dapat merumuskan terlebih dahulu yang akan dibahas. Adapun rumusan masalahnya adalah adakah pengaruh evaluasi kerja terhadap

\section{TINJAUAN PUSTAKA}

\subsection{Penelitian Terdahulu}

Penelitian terdahulu sangatlah penting sebagai dasar pijakan dalam rangka menyusun proposal skripsi ini. Terdapat beberapa penelitian terdahulu yang akan mengarahkan penelitian ini diantaranya yaitu Tri Widodo, tahun 2014 yang menunjukkan adanya pengaruh positif dan siknifikan dari masing-masing variabel yaitu Lingkungan kerja budaya organisasi, dan kepemimpinan terhadap kinerja pegawai Kecamatan Sidorejo Kota Salatiga. Damayanti (2012) menunjukkan Terdapat pengaruh yang segnifikan secara simulatan antara variabel lingkungan kerja yang terdiri dari lingkungan internal terhadap produktivitas kerja karyawan. Kemudian diperkuat oleh Suharni Rahayu (2017) yang menunjukkan bahwa promosi jabatan dan kinerja karyawan PT. Garuda terdapat pengaruh besar antara variabel promosi jabatan terhadap variabel kinerja

\section{Evaluasi Jabatan}

Berdasarkan definisi yang telah diuraikan, bahwa evaluasi jabatan adalah suatu proses mengumpulkan, mengolah, menafsirkan serta kinerja karyawan di Perum Bulog Divre Nusa Tenggara Barat?

\subsection{Tujuan dan Manfaat Penelitian}

1.3.1 Tujuan penelitian

Berdasarkan rumusan masalah diatas, maka tujuan penelitian proposal ini adalah untuk mengetahui ada atau tidak pengaruh evaluasi kerja karyawan terhadap kinerja karyawan di Perum Bulog Divre Nusa Tenggara Barat.

\subsubsection{Manfaat penelitian}

\section{Manfaat teoritis}

Dapat menambah ilmu pengetahuan dan pengalaman dalam menerapkan ilmu yang didapat di bangku kuliah dengan fakta-fakta yang ada di lapangan khususnya tentang pengaruh evaluasi jabatan terhadap produktivitas kerja pegawai.

2. Manfaat bagi tempat penelitian Sebagai referensi untuk mengevaluasi kinerja pegawai terhadap pemberian jabatan.

3. Manfaat bagi penulis Hasil penelitian ini dapat menambah pengetahuan, memperluas wawasan dan pengalaman yang berharga di bidang dunia

kerja

Pengertian Evaluasi Jabatan

Evaluasi jabatan merupakan dasar bagi sebagian besar aktivitas manajmen sumber daya manusia, karena informasi yang diperoleh dari evaluasi jabatan dapat dipergunakan untuk menarik, seleksi, pengupahan, pelatihan karyawan, dan sebagainya. Dalam konteks strategik, evaluasi jabatan diperlukan untuk mendukung perusahaan dalam mengadakan perubahan-perubahan terhadap jabatan yang telah ada, baik melalui penciptaan jabatan baru maupun pengurangan terhadap jabatan yang telah ada.

Menurut Mondy (2018), analisis jabatan adalah proses sistematik untuk menentukan keterampilan-keterampilan, tugas-tugas, dan pengetahuan yang dibutuhkan untuk menjalankan pekerjaan-pekerjaan dalam suatu organisasi.

Menurut Dessler (2014), evaluasi jabatan adalah prosedur yang dilakukan untuk menentukan tugas-tugas dari suatu jabatan, serta spesifikasi sumber daya manusia yang tepat untuk mengisi jabatan tersebut.

menyusun secara sistematis segala fakta mengenai suatu jabatan. 
Hasil analisa jabatan memberikan informasi yang menguraikan berbagai hal mengenai jabatan tersebut, yang dapat digunakan untuk mengembangkan uraian jabatan (job description) dan spesifikasi jabatan (job specification). Uraian jabatan adalah suatu daftar tugas-tugas, tanggung jawab, hubungan laporan, dan kondisi kerja. Sedangkan spesifikasi jabatan adalah suatu daftar dari suatu jabatan, meliputi pendididkan, keterampilan, keperibadian dan lain-lain yang sesuai dengan jabatan tersebut.

Menurut Dessler (2008), uraian jabatan adalah suatu daftar tugas-tugas, tanggung jawab, hubungan laporan, kondisi kerja, tanggung jawab kepedulian suatu jabatan dan suatu produk dari analisis jabatan. Dan spesifikasi jabatan adalah suatu daftar persyaratan tenaga kerja untuk suatu jabatan, yakni pendidikan, keterampilan, keperibadian, dan lainlain sesuai produk dari analisis jabatan.

\subsubsection{Uraian Jabatan (Job Description)}

Uraian jabatan adalah informasi tertulis yang menguraikan tugas dan tanggung jawab, kondisi pekerjaan, hubungan pekerjaan dan aspek- aspek pekerjaan pada suatu jabatan tertentu dalam organisasi. "rincian pekerjaan yang berisi iformasi menyeluruh tentang tugas atau kewajiban, tanggung jawab, dan kondisi-kondisi yang diperlukan apabila pekerjaan itu dikerjakan" (Siswanto, 2002)

Hal-hal yang perlu dicantumkan dalam uraian jabatan pada umumnya meliputi:

a. Identifikasi jabatan, yang berisi informasi tentang nama jabatan, bagian dan kode jabatan dalam suatu perusahaan.

b. Ikhtisar jabatan, yang berisi informasi tentang jabatan tersebut, yang juga memberikan suatu definisi singkat yang berguna sebagai tambahan atas informasi pada identifikasi jabatan, apabila nama jabatan tidak cukup jelas.

c. Tugas-tugas yang harus dilaksanakan. Bagian ini adalah merupakan inti dari uraian jabatan dan merupakan bagian yang paling sulit untuk dituliskan secara tepat. Untuk itu, bisa dimulai menyusunnya dengan mencoba menjawab pertanyaan-pertanyaan tentang apa dan mengapa suatu pekerjaan dilaksanakan, dan bagaimana cara melaksanakannya.

d. Hubungan dengan jabatan lain. Bagian ini menjelaskan hubungan vertical dan horizontal jabatan ini dengan jabatan-jabatan lainnya dalam hubungannya dengan jalur promosi, aliran serta prosedur kerja.

e. Kondisi kerja, yang menjelaskan tentang kondisi fisik lingkungan kerja dari suatu jabatan. Misalnya panas, dingin, berdebu, ketal, bising dan lain-lain terutama kondisi kerja yang berbahaya.

Sesuai dengan pengertiannya bahwa deskripsi jabatan adalah kumpulan informasi tertulis tentang suatu jabatan, maka menurut Ardana, (2012:39) deskripsi jabatan tersebut memberikan beberapa manfaat, antara lain :

a. Deskripsi jabatan membantu menghindari adanya kebingungan dan memberikan pemahaman dalam melaksanakan pekerjaan.

b. Dapat menghindari tumpang tindih tanggung jawab.

2.3 Produktivitas Kerja

\subsubsection{Pengertian Produktivitas Kerja}

Menurut Sinungan (2009: produktivitas secara umum diartikan sebagai hubungan antara keluaran (barang-barang atau jasa) dengan masukan (kerja, bahan, uang). Masukan sering dibatasi dengan masukan tenaga kerja, sedangkan keluaran sering diukur dalam kesatuan fisik, bentuk, dan nilai. Produktivitas adalah suatu pendekatan indisipliner untuk menentukan tujuan yang efektif, pembuatan rencana, aplikasi penggunaan cara yang produktivitas untuk menggunakan sumber sumber secara efisien, dan tetap menjaga adanya kualitas yang tinggi. Produktivitas mengikutsertakan pendayagunaan secara terpadu sumber daya manusia dan keterampilan, barang modal teknologi, manajemen, informasi, energi, dan sumber-sumber lain menuju kepada pengembangan dan peningkatan standar hidup untuk seluruh masyarakat, melalui konsep produktivitas semesta atau total.

Menurut Sutrisno (2011:102) produktivitas kerja adalah rasio dari hasil kerja dengan waktu yang dibutuhkan untuk menghasilkan produk dari seseorang tenaga kerja. Selain itu Produktivitas kerja adalah ukuran yang menunjukan pertimbangan antara input dan output yang dikeluarkan perusahaan serta peran tenaga kerja yang memiliki persatuan waktu. Dengan kata lain mengukur efisien memerlukan identifikasi dari hasil kerja, seperti misalnya jumlah sumber daya yang digunakan untuk menghasilkan output tersebut.

\subsubsection{Teori Produktivitas}


Menurut Herjanto produktivitas adalah berupa ukuran yang dapat menyatakan bagaimana suatu sumber dapat dinyatakan baik dan dapat di atur serta dapat dimanfaatkan untuk dapat mencapai suatu hasil yang optimal. interaksi terpadu antara tiga faktor yang mendasar, yaitu: Investasi, Manajemen, dan Tenaga Kerja.

a. Investasi

Komponen pokok dari investasi adalah modal, karena modal merupakan landasan gerak suatu usaha, namun modal saja tidak cukup, untuk itu harus ditambah dengan komponen teknologi, terutama teknologi yang bisa memberi dukungan kepada kemajuan pembangunan nasional, ditingkat mikro tentunya teknologi yang mampu mendukung kemajuan usaha atau perusahaan

Berkaitan erat dengan penguasa teknologi ini ialah adanya riset. Melalui riset maka akan dapat dikembangkan penyempurnaan produk atau bahkan dapat menghasilkan formula-formula baru yang sangat penting artinya bagi kemajuan suatu usaha. Karena itu keterpaduan antara modal teknologi dan riset akan membawa perusahaan berkembang dan dengan perkembangan itu maka outputnya akan bertambah.

b. Manajemen

$\begin{array}{ccc}\text { Kelompok manajemen } & \text { dalam } \\ \text { organisasi } & \text { bertugas } & \text { pokok }\end{array}$
menggerakkan orang-orang lain untuk bekerja sedemikian rupa sehingga tujuan tercapai. Hal-hal yang kita hadapi dalam manajemen, terutama dalam organisasi modern ialah semakin cepatnya cara kerja sebagai pengaruh langsung dari kemajuankemajuan yang diperoleh dalam bidang ilmu pengetahuan dan teknologi yang mempengaruhi seluruh aspek organisasi seperti proses produksi distribusi, pemasaran, dan lain-lain. Kemajuan teknologi yang berjalan cepat maka harus diimbangi dengan proses yang terus menerus melalui pengembangan sumber daya manusia, yakni melalui pendidikian dan pengembangan.
Dari pendidikan, latihan dan pengembangan tersebut akan menghasilkan skill yang menguasai aspek-aspek manajerial, yaitu: Technical Skill, tenaga kerja yang memiliki kualifikasi tertentu, terampil, dan ahli dibidang teknisi, dan manajerial skill, kemampuan dan keterampilan dalam bidang manajemen tertentu, mampu mengandalkan atau melakukan kegiatan-kegiatan analisa kuantitatif dan kualitatif dalam memecahkan masalah-masalah yang dihadapi organisasi.

c. Tenaga Kerja

Hal-hal yang harus diperhatikan dalam kaitannya dengan faktor-faktor tenaga kerja ini adalah: motivasi, pengabdian, disiplin, etos kerja, produktivitasnya, dan masa depannya, dan hubungan industrial yang serasi dan harmonis dalam suasana keterbukaan. Dengan demikian dapat disimpulkan bahwa meskipun ada sejumlah perbedaan mengenai definisi produktivitas yang tergantung pada keadaan yang nyata dan tujuan-tujuan yang ada, pendekatan umum menyusun pola dari model produktivitas adalah mengidentifikasi output dan komponen-komponen input yang benar dan sesuai dengan tujuan jangka panjang, menengah dan pendek perusahaan, sektor maupun pembangunan Negara.

\subsubsection{Indikator Produktivitas Kerja}

Adanya produktivitas kerja diharapkan pekerja akan terlaksana secara efisien dan efektif, sehingga ini semua akhirnya sangat diperlukan dalam pencapaian tujuan yang sudah ditetapkan. Untuk mengukur produktivitas kerja, diperlukan suatu indikator.

Menurut Sutrisno (2010: 104) indikator-indikator produktivitas kerja adalah:

1. Kemampuan

2. Meningkatkan hasil yang dicapai

3. Semangat kerja

4. Pengembangan diri

5. Mutu

6. Efisien

Kemampuan adalah kemampuan untuk melaksanakan tugas. Kemampuan seorang karyawan sangat bergantuk 
pada keterampilan yang dimiliki serta profesionalisme mereka dalam bekerja. Ini memberikan daya untuk menyelesaikan tugas-tugas yang diembankan kepada mereka.

Meningkatkan hasil yang dicapai, adalah salah satu yang dapat dirasakan baik oleh yang mengerjakan maupun yang menikmati hasil pekerjaan tersebut. Jadi, upaya untuk memanfaatkan produktivitas kerja bagi masing-masing yang terlibat dalam suatu pekerjaan.

Semangat kerja, adalah usaha untuk lebih baik dari hari kemarin. Indicator ini dapat dilihat dari etos kerja dan hasil yang dicapai dalam suatu hari kemudian dibandingkan dengan hari sebelumnya.

Pengembangan diri adalah mengembangkan diri untuk meningkatkan kemampuan kerja. Pengembangan diri dapat dilakukan dengan meliahat tantangan dan harapan dengan apa yang akan dihadapi. Sebab semakin kuat tantangannya, pengembangan diri mutlak dilakukan. Begitu juga harapan untuk menjadi lebih baik pada gilirannya akan sangat berdampak pada keinginan karyawan untuk meningkatkan kemampuan.

Mutu adalah hasil pekerjaan yang dapat menunjukan kualitas kerja seorang pegawai. Jadi, meningkatkan mutu bertujuan untuk memberikan hasil yang lebih baik yang pada gilirannya akan sangat berguna bagi perusahaan dan dirinya sendiri.

Efisien, adalah perbandingan antara hasil yang dicapai dengan keseluruhan sumber daya yang digunakan. Masukan dan keluaran merupakan aspek produktivitas yang memberikan pengaruh yang cukup signifikan bagi karyawan.

\subsection{Konsep Penelitian}

Berdasarkan tinjauan landasan teori dan penelitian terdahulu, maka dapat disusun sebuah konsep penelitian seperti yang tersaji dalam gambar.

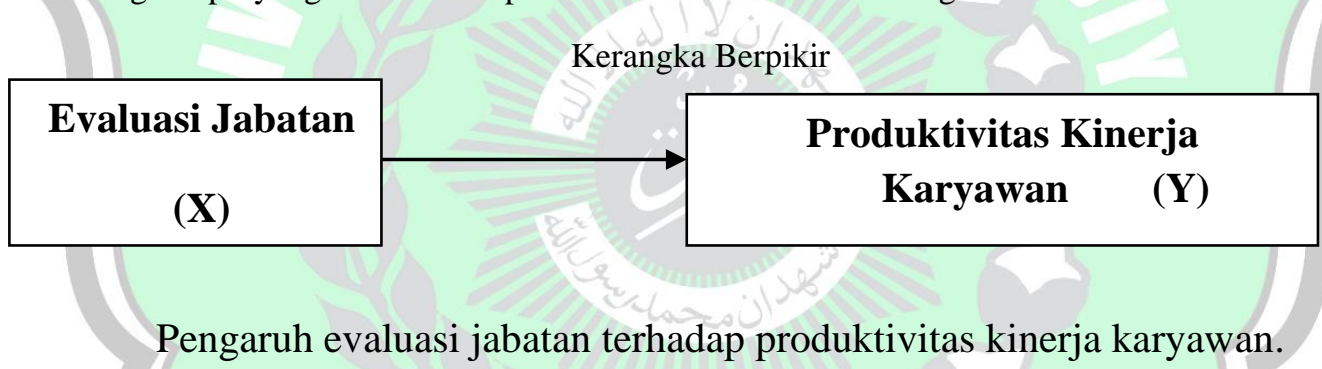

\subsection{Hipotesis}

Hipotesis merupakan jawaban sementara atau dugaan sementara dimana masih bersifat teoritis, titik tolak dalam merumuskan hipotesis adalah dari rumusan masalah.

\section{METODE PENELITIAN}

\subsection{Metode Penelitian}

Penelitian ini menggunakan metode penelitian kuantitatif, sedangkan jenis penelitian ini asosiatif. Menurut Sugiyono (2010:8) Penelitian kuantitatif adalah Penelitian dengan memperoleh data yang berbentuk angka.

\subsection{Lokasi Penelitian}

Tempat penelitian dilakukan di Perum Bulog Divre Nusa Tenggara Barat. Lokasi ini dipilih dengan pertimbangan bahwa selain sangat relevan dengan permaslahan penelitian yang didapat pada saat magang, juga dapat
H1 : Evaluasi jabatan berpengaruh positif terhadap produktivitas kinerja karyawan

mengakses informasi yang dibutuhkan dalam penelitian.

\subsection{Populasi dan Sampe}

\subsubsection{Populasi}

Populasi adalah wilayah generalisasi yang terdiri atas objek/subjek yang mempunyai kualitas dan karakteristik tertentu yang ditetapkan oleh peneliti untuk dipelajari dan kemudian ditarik kesimpulannya (Sugiyono, 2012:90). Populasi penelitian adalah pegawai Perum Bulog Divre ntb sejumlah 60 orang. 
Tabel 1. Populasi dan Sampel

\begin{tabular}{|c|l|c|c|c|}
\hline No. & \multicolumn{1}{|c|}{ Responden Pegawai } & $\begin{array}{c}\text { Populasi } \\
(\text { orang) }\end{array}$ & $\begin{array}{c}\text { Proporsional } \\
(\mathbf{1 0 0 \% )}\end{array}$ & Sampel \\
\hline 1. & Seksi gasar & 15 & & 15 \\
\hline 2. & Seksi komersil & 15 & & 15 \\
\hline 3. & Seksi opp & 15 & & 15 \\
\hline 4. & Seksi keuangan & 15 & & 15 \\
\hline
\end{tabular}

\subsection{Metode Pengumpulan Data}

Metode pengumpulan data yang digunakan dalam penelitian ini dalam usaha mendapatkan data yang dibutuhkan, penelitian melakukan pengumpulan data sebagai berikut:

\subsubsection{Observasi}

Menurut Riduwan (2004) Observasi adalah teknik pengumpulan data, peneliti melakukan pengamatan secara langsung ke objek penelitian untuk melihat dari dekat kegiatan yang dilakukan. Yaitu pada Sub Driver Perum Bulog Nusa Tenggara Barat, sehingga diperoleh data yang diharapkan dapat membantu proses pemecahan masalah.

\subsubsection{Wawancara}

Menurut Nazir (1988) Wawancara adalah proses memperoleh keterangan untuk tujuan penelitian dengan cara tanya jawab sambil bertatap muka atara si penanya atau pewawancara.

\subsubsection{Kuesioner}

Menurut Sugiyono (2014:193), "mengemukakan bahwa pertanyaan peneliti dan jawaban responden dapat dikemukakan secara tertulis melalui suatu kuesioner". Kuesioner dapat didisribusikan dengan berbagai cara, antara lain kuesioner disampaikan langsung oleh peneliti, ditempatkan ditempat yang ramai dikunjungi banyak orang, dikirim melalui pos, faximel atau menggunakan teknik komputer. Penulis menyebarkan dan teknik teknik pengumpulan data melalui penyebaran kuesioner (daftar pertanyaan isian) agar diisi langsung oleh responden, kemudian responden tersebut memberikan jawaban berdasarkan pertanyaan yang diberikan.

\subsection{Skala Pengukuran Interval}

Alat ukur yang digunakan dalam penelitian ini berupa kuesioner yang dibuat secara terstruktur, didalamnya terkandung beberapa item pertanyaan-pertanyaan beserta alternatif jawaban yang sesuai dengan keadaan yang sebenarnya kuesioner ini dibuat mengingat satuan pengukuran yang digunakan scoring, yaitu pemberian nilai pada alternative jawaban yang disediakan dalam pertanyaan-pertanyaan penelitian. Penelitian ini menggunakan skala ordinal yang ditransformasikan kedalam skala interval, adapun ukuran pemberian skornya berdasarkan skala likert.

Menurut Sugiyono (2014: 137) skala likert umumnya menggunakan lima angka penilaian.

Jawaban Sangan Setuju (SS) diberi skor : 5

Jawaban Setuju (S)

Jawaban Ragu (R)

$: 4$

Jawaban Tidak Setuju (TS)

Jawaban Sangat Tidak Setuju (STS) $\quad: 1$

\subsection{Teknik Analisa Data}

\subsection{1 \\ Uji Instrumen Penelitian}

1. Analisa Regresi Linear

Regresi Linear adalah sebuah pendekatan untuk memodelkan hubungan antara variable terikat Y dan satu atau lebih variable bebas yang disebut $X$. salah satu kegunaan dari regresi linear adalah untuk melakukan prediksi berdasarkan data-data yang telah dimiliki sebelumnya.

2. Uji Hipotesis

a. Uji T

Uji T pada dasarnya menunjukkan seberapa jauh pengaruh satu variabel independen secara individual dalam menerangkan variasi variabel independen (Ghozali, 2005). Dasar pengambilan keputusan dalam pengujian ini adalah sebagai berikut (Ghozali, 2005) :

1) Jika angka probabilitas signifikansi > 0,5 maka $\mathrm{H} 0$ diterima dan $\mathrm{H} 1$ ditolak. Hal ini berarti bahwa variabel bebas (kualitas produk dan harga) secara individual tidak 
memiliki pengaruh signifikan terhadap variabel terikat (keputusan pembelian).

2) Jika angka probabilitas signifikansi $<0,5$ maka $\mathrm{H} 0$ ditolak dan $\mathrm{H} 1$ diterima. Hal ini berarti bahwa variabel bebas (kualitas produk dan harga) secara individual memiliki pengaruh signifikansi terhadap variabel terikat

(keputusan

b. Uji F pembelian).

Uji $F$ digunakan untuk mengetahui apakah variabel berpengaruh terhadap variabel terikat secara bersama-sama atau simultan. Pengujian dilakukan dengan membandingkan antara $\mathrm{F}$ hitung dan $F$ tabel pada taraf signifikansi sebesar $5 \%$ atau $\alpha=$ 0,5 . Dasar penarikan kesimpulan atas pengujian ini adalah sebagai berikut :

1) Jika $\mathrm{F}$ hitung $>\mathrm{F}$ tabel maka $\mathrm{H} 1$ ditolak dan $\mathrm{HO}$ diterima. Hal ini berarti bahwa variabel bebas secara bersama-sama atau simultan tidak memiliki signifikan terhadap variabel terikat.

2) Jika $F$ hitung $<F$ tabel maka $\mathrm{H} 1$ dan $\mathrm{H} 0$ diterima. Hal ini berarti bahwa variabel bebas secara bersama-sama atau simultan tidak memiliki pengaruh signifikan terhadap variabel terikat.

\section{Uji R Square / Determinasi (R2)}

Koefisien determinasi (R2) dimaksudkan untuk mengetahui tingkat ketepatan yang paling baik dalam analisa regresi, hal ini ditunjukkan oleh besarnya koefisien determinas (R2) antara 0 (nol) sampai dengan 1 (satu). Jika koefisien determinasi nol berarti variabel independen sama sekali tidak berpengaruh terhadap variabel dependen. Apabila koefisien determinasi semakin mendekati satu, maka dapat dikatakan bahwa variabel independen berpengaruh terhadap variabel dependen. Karena variabel independen pada penelitian ini lebih dari 2, maka koefisien determinasi yang digunakan adalah Adjusted $\mathrm{R}$ Square (Iman Ghozali, 2005). Dari koefisien determinasi (R2) ini dapat diperoleh suatu nilai untuk mengukur besarnya sumbangan dari beberapa variabel $\mathrm{X}$ terhadap variasi naik turunnya variabel $\mathrm{Y}$ yang biasanya dinyatakan dalam persentase.

\section{HASIL PENELITIAN DAN PEMBAHASAN} 1.1 Hasil Penelitian

\subsubsection{Gambaran Umum Lokasi Penelitian}

1. Sejarah Singkat Perum Bulog

Perjalanan Perum BULOG dimulai pada saat dibentuknya BULOG pada tanggal $10 \mathrm{Mei}$ 1967 berdasarkan keputusan presidium kabinet No.114/U/Kep/5/1967, dengan tujuan pokok untuk mengamankan penyediaan pangan dalam rangka menegakkan eksistensi Pemerintahan baru.

Selanjutnya direvisi melalui Keppres No. 39 tahun 1969 tanggal 21 Januari 1969 dengan tugas pokok melakukan stabilisasi harga beras, dan kemudian direvisi kembali melalui Keppres No 39 tahun 1987, yang dimaksudkan untuk menyongsong tugas BULOG dalam rangka mendukung pembangunan komoditas pangan yang multi komoditas. Perubahan berikutnya dilakukan melalui Keppres No. 103 tahun 1993 yang memperluas tanggung jawab BULOG mencakup koordinasi pembangunan pangan dan meningkatkan mutu gizi pangan, yaitu ketika Kepala BULOG dirangkap oleh Menteri Negara Urusan Pangan.

Pada tahun 1995, keluar Keppres No 50, untuk menyempurnakan struktur organisasi BULOG yang pada dasarnya bertujuan untuk lebih mempertajam tugas pokok, fungsi serta peran BULOG. Oleh karena itu, tanggung jawab BULOG lebih difokuskan pada peningkatan stabilisasi dan pengelolaan persediaan bahan pokok dan pangan

Tugas pokok BULOG sesuai Keppres tersebut adalah mengendalikan harga dan mengelola persediaan beras, gula, gandum, terigu, kedelai, pakan dan bahan pangan lainnya, baik secara langsung maupun tidak langsung, dalam rangka menjaga kestabilan harga bahan pangan bagi produsen dan konsumen serta memenuhi kebutuhan pangan berdasarkan kebijaksanaan umum Pemerintah. Namun tugas tersebut berubah dengan keluarnya Keppres No. 45 tahun 1997, dimana komoditas yang dikelola BULOG dikurangi dan tinggal beras dan gula. Kemudian melalui Keppres No 19 tahun 1998 tanggal 21 Januari 1998, Pemerintah 
mengembalikan tugas BULOG seperti Keppres No 39 tahun 1968. Selanjutnya melalu Keppres No 19 tahun 1998, ruang lingkup komoditas yang ditangani BULOG kembali dipersempit seiring dengan kesepakatan yang diambil oleh Pemerintah dengan pihak IMF yang tertuang dalam Letter of Intent (LoI).

Dalam Keppres tersebut, tugas pokok BULOG dibatasi hanya untuk menangani komoditas beras. Sedangkan komoditas lain yang dikelola selama ini dilepaskan ke mekanisme pasar. Arah Pemerintah mendorong BULOG menuj u suatu bentuk badan usaha mulai terlihat dengan terbitnya Keppres No. 29 tahun 2000, dimana didalamnya tersirat BULOG sebagai organisasi transisi (tahun 2003) menuju organisasi yang bergerak di bidang jasa logistik di samping masih menangani tugas tradisionalnya.

Pada Keppres No. 29 tahun 2000 tersebut, tugas pokok BULOG adalah melaksanakan tugas Pemerintah di bidang manaj emen logistik melalui pengelolaan persediaan, distribusi dan pengendalian harga beras (mempertahankan Harga Pembelian Pemerintah (HPP)), serta usaha jasa logistik sesuai dengan peraturan perundang-undangan yang berlaku. Arah perubahan tesebut semakin kuat dengan keluarnya Keppres No 166 tahun 2000, yang selan utnya diubah menjadi Keppres No. 103/2000.

Kemudian diubah lagi dengan Keppres No. 03 tahun 2002 tanggal 7 Januari 2002 di mana tugas pokok BULOG masih sama dengan ketentuan dalam Keppers No 29 tahun 2000, tetapi dengan nomenklatur yang berbeda dan memberi waktu masa transisi sampai dengan tahun 2003. Dan pada akhirnya, sejak tanggal 20 Januari 2003 LPDN Bulog secara resmi berubah menjadi Perum Bulog berdasarkan Peraturan Pemerintah RI No. 7 tahun 2003 yang kemudian direvisi menjadi PP RI No. 6 tahun 2003. Peluncuran Perum Bulog ini dilakukan di Gedung Arsip Nasional Jakarta pada tanggal 10 Mei 2003.

\section{Visi dan Misi Perum BULOG Divisi} Regional Nusa Tenggara Barat Visi

"Menjadi Perusahaan yang Unggul dalam Mewujudkan Kedaulatan Pangan".

Misi

1. Memberikan pelayanan prima kepada masyarakat dan pemangku kepentingan lainnya untuk memenuhi kebutuhan pangan pokok.

2. Mencapai pertumbuhan usaha yang berkelanjutan.
3. Menerapkan tata kelola perusahaan yang baik.

3. Nilai-nilai Perusahaan

a. INTEGRITAS. Konsisten antara ucapan dan perilaku sesuai dengan norma dan prinsip-prinsip tata kelola perusahaan yang baik (Good Corporate Governance).

b. PROFESIONAL. Bekerja cerdas berdasarkan kompetensi terbaik dan penuh tanggung jawab.

c. DINAMIS. Selalu bersemangat untuk tumbuh dan berkembang menjadi yang terbaik.

d. PEDULI. Memperhatikan dan memenuhi kebutuhan serta memberi solusi terbaik kepada pemangku kepentingan.

e. TOTALITAS. Mendayagunakan seluruh potensi dan sumber daya yang ada serta bersinergi untuk mencapai tujuan Perusahaan.

Tugas pokok masing-masing bagian di Perusahaan Umum (Perum) BULOG Divisi Regional Nusa Tenggara Baratadalah sebagai berikut:

1. Kepala Divisi Regional

a. Melaksanakan kebijakan perusahaan dan menyelenggarakan kegiatan pengadaan, operasional dan pelayanan publik, komersial, pengelolaan administrasi dan keuangan di wilayah kerjanya.

b. Khusus untuk pengelolaan administrasi dan keuangan termasuk SDM, hukum, umum, sekretariat, humas, teknologi informasi, keuangan, akuntansi serta manajemen risiko dan kepatuhan, Kepala Divisi Regional melaksanakan koordinasi dengan Wakil Divisi Regional.

c. Kepala Divisi Regional mempunyai fungsi merencanakan mengoodinasikan, mengendalikan, dan mengevaluasi pelaksanaan:

1) Pengadaan gabah/beras dan pangan pokok lain;

2) Operasional dan tugas pelayanan publik;

3) Usaha bisnis komersial

4) Pengelolaan keuangan;

5) Pengelolaan sumber daya manusia dan umum dan,

6) Pembinaan Subdivre, Gudang, Pusat Distribusi dan Unit Pengolahan.

2. Wakil Kepala Divisi Regional 
a. Membantu Kepala Divisi Regional dalam menyelenggarakan tugas pokok dan fungsinya;

b. Mengelola fungsi administrasi dan keuangan termasuk SDM, hukum, umum, sekretariat, humas, teknologi informasi, keuangan, akuntansi serta manajemen resiko dan kepatuhan;

c. Mewakili Kepala Divisi Regional apabila berhalangan.

d. Mempunyai fungsi membantu Kepala Divisi Regional dalam merencanakan, mengkoordinasikan, mengendalikan dan mengevaluasi pelaksanaan:

1) Pengadaan gabah/beras dan pangan pokok lain;

2) Operasional dan tugas pelayanan publik;

3) Usaha bisnis komersial;

4) Pengelolaan keuangan;

5) Pengelolaan sumber daya manusia dan umum

3. Bagian Pengadaan
a. Kepala Bidang Pengadaan
mempunyai tugas pokok
melaksanakan kegitan analisis harga dan pasar, program kemitraan dan on farm, pengadaan gabah, beras dan pengadaan pangan pokok lain.
Kepala Bagian Pengadaan mempunyai fungsi merencakan, mengkoordinasikan, mengendalikan dan mengevaluasi pelaksanaa:
1) Analisis harga dan pasar;
2) Program kemitraan dan on farm;
3) Pengadaan gabah/beras;
4) Pengadaan pangan pokok lain.

b. Kepala Seksi Analisis Harga dan Pasar, mempunyai tugas pokok melakukan pengamatan dan pengumpulan data harga, kondisi dan struktur pasar, tata niaga komoditas gabah, beras dan pangan pokok lain serta melakukan market intelligence; penyimpan data meliputi perkiraan permintaan komoditas yang dibutuhkan pasar, pasokan komoditas, perencanaan jaringan dan penyaluran; penjualan; penyediaan data statistik, rangkuman penyusunan rencana kerja Divisi Regional untuk mendukung kegiatan operasional dan komersial; serta memantau, mengevaluasi, dan melaporkan kegiatan analisis harga dan pasar.

c. Kepala Seksi Kemitraan dan On farm, mempunyai tugas pokok melakukan pendataan, seleksi, evaluasi dan pembinaan mitra kerja pengadaan; penyiapan rencana, penyediaan dan pengelolaan lahan untuk kegiatan on farm (padi dan pangan pokok lain) baik secara mandiri maupun dengan pola kerjasama kemitraan atau sinergi antar badan usaha; serta memantau, mengevaluasi, dan melaporkan kegiatan kemitraan dan on farm.

d. Kepala Seksi Pengadaan Gabah/Beras, mempunyai tugas pokok melakukan penyiapan program pengadaan gabah dan beras medium/premium serta perangkat pemeriksa kualitas di laboratorium pemeriksaan kualitas; penghitungan kebutuhan yang meliputi bahan pendukung (karung pembungkus, benang kuralon dan lainlain), L/C pengadaan, biaya eksploitas; penyiapan administrasi pengadaan seperti kontrak jual beli dan dokumen lainnya; serta memantau,mengevaluasi, $\longrightarrow$ dan melaporkan kegiatan pengadaan gabah dan beras medium/ premium hasil produksi dalam negeri.

e. Kepala Seksi Pengadaan Pangan Pokok Lain, mempunyai tugas pokok melakukan penyiapan program pengadaan pangan pokok lain meliputi hasil pertanian (jagung, kedelai, cabai, bawang merah dan lainnya), hasil industri (tepung terigu, minyak goreng, gula dan lainnya) dan hasil peternakan dan perikanan (daging sapi, daging ayam, ikan dan lainnya); penghitungan kebutuhan yang meliputi bahan pendukung (karung pembungkus, benang kuralon dan lainlain), L/C pengadaan, biaya eksploitasi, penyiapan administrasi pengadaan seperti kontrak jual beli, dan dokumen lainnya; serta memantau, mengevaluasi dan melaporkan kegiatan pengadaan pangan pokok lain.

4. Bidang Operasional dan Pelayanan Publik

a. Kepala Bidang Operasional dan Pelayanan Publik, mempunyai tugas pokok melaksanakan kegiatan pengolahan, pengolahan pergudangan, dan pemeliharaan sarana pengolahan, persediaan dan penyediaan angkutan, perawatan kualitas dan pengendalian mutu, serta penyaluran beras, pangan pokok lainnya dan Cadangan Pangan 
Pemerintah (CPP) untuk pelayanan publik.

Kepala Bidang Operasional dan Pelayanan Publik mempunyai fungsi merencanakan, mengoodinasikanm mengendalikan, dan mengevaluasi pelaksanaan:

1) Pengolahan

2) Pergudangan, persediaan dan angkutan

3) Perawatan dan pengendalian mutu 4) Pelayanan publik

b. Kepala Seksi Pengolahan, mempunyai tugas pokok melakukan penyiapan rencana operasional, sarana dan prasarana, administrasi, biaya, dan bahan pendukung kemasan, mesin jahit, benang kuralon) untuk kegiatan pengolahan gabah/beras dan pangan pokok lainnya; standarisasi mutu/Good Manufacturing Practice (GMP) termasuk penggilingan gabah dan mesin pengolahan lainnya; penjadwalan dan pelaksanaan kegiatan pemeliharaan sarana pengolahanan yang dibutuhkan termasuk biayanya, serta memantau, mengevaluasi, dan melaporkan kegiatan pengolahan.

c. Kepala Seksi Pergudangan, Persediaan dan Angkutan, mempunyai tugas pokok melakukan pengelolaan pergudangan meliputi kebutuhan kapasitas penyimpanan dan sarana gudang, biaya sewa gudang, biaya operasional dan biaya rawat ringan gudang; dan Keselamatan dan Kesehatan Kerja; administrasi persediaan meliputi jumlah, posisi, dan mutasi persediaan gabah, beras dan pangan pokok lainnya; penyiapan pelaksanaan operasional dan administrasi angkutan movenas, movereg, dan movelok dan angkutan pangan pokok lainnya untuk mendukung kegiatan pelayanan publik dan komersial; serta memantau, mengevaluasi dan melaporkan kegiatan pengelolaan pergudangan, persediaan dan angkutan.

d. Kepala Seksi Perawatan dan Pengendalian Mutu, mempunyai tugas pokok melakukan operasional dan administrasi perawatan dan pengendalian mutu; penyiapan sarana dan prasarana perawatan kualitas; penghitungan dan pengajuan biaya perawatan kualitas; standarisasi mutu gabah, beras dan pangan pokok lainnya termasuk sarana penunjangnya; pengendalian dokumen dan manajemen standarisasi mutu(ISO, SNI dan standarisasi lainnya); serta memantau, mengevaluasi dan melaporkan kegiatan perawatan dan pengendalian mutu.

e. Kepala Seksi Pelayanan Publik, mempunyai tugas pokok melakukan operasional dan administrasi penyaluran beras kepada kelompok masyarakat berpendapatan rendah, kelembagaan pemerintah dan CPP; pengajuan kebutuhan biaya operasional, eksploitasi, sosialisasi dan koordinasi dengan pihak lain; penghimpunan data dan penyelesaian pengaduan masyarakat; administrasi dokumen penagihan penyaluran beras; serta memantau, mengevaluasi, dan melaporkan kegiatan pelayanan publik.

5. Bidang Komersial

a. Kepala Bidang Komersial, mempunyai tugas pokok melaksanakan kegiatan pengembangan, pemasaran, pengendalian perdagangan, penjualan langsung, penjualan distributor dan toko binaan.

Kepala Bidang Komersial mempunyai fungsi merencanakan, mengoodinasikan, mengendalikan dan mengevaluasi pelaksanaan:

1) Pengembangan produk dan pemasaran

2) Pengendalian perdagangan

3) Penjualan langsung, penjualan distributor dan tokobinaan

4) Supervisi unit bisnis

b. Kepala Seksi Produk dan Pemasaran, mempunyai tugas pokok melakukan analisis pengembangan produk perberasan, produk hasil pertanian dan industri serta produk hasil peternakan dan perikanan beserta turunannya sesuai permintaan pasar; pemantauan spesifikasi, kualitas, dan hargapenjualan produk dan kemasannya; pemasaran dan promosi produk; kerjasama pemasaran dan promosi dengan pihak lain; penghitungan dan pengajuan biaya promosi; evaluasi kepuasan dan keluhan pelanggan; serta memantau, 
mengevaluasi, dan melaporkan kegiatan produk dan pemasaran.

c. Kepala Seksi Pengendalian Perdagangan, mempunyai tugas pokok melakukan perencanaan (forecasting) penjualan produk dan strategi penetapan harga penjualan beserta keuntungan; pengendalian persediaan produk dagang, penempatan dan pengiriman produk dagang di/dari pusat distribusi (distribution center); distribusi produk antar tempat, modal, biaya penjualan, penagihan dan penerimaan hasil penjualan; penyiapan laporan manajemen Bidang Komersial; serta memantau, mengevaluasi, dan melaporkan kegiatan pengendalian perdagangan.

d. Kepala Seksi Penjualan, mempunyai tugas pokok melakukan penjualan produk secara langsung kepada kelembagaan pemerintah dan non pemerintah, badan usaha milik negara, dan badan usaha lainnya termasuk hotel, restoran dan katering, badan usaha pemerintah, swasta dan badan usaha lainnya; penjualan produk secara tidak langsung melalui distributor dan jaringan toko binaan; administrasi biaya operasional dan hasil penjualan produk; serta memantau, mengevaluasi, dan melaporkan kegiatan penjualan.

6. Bidang Administrasi Keuangan

a. Kepala Bidang Administrasi dan Keuangan, mempunyai tugas pokok melaksanakan pengelolaan sumber daya manusia dan hukum, sekretariat dan hubungan masyarakat (humas),umum, dan teknologi informasi, keuangan, akuntasi, perpajakan, manajemen risiko, dan kepatuhan.

b. Kepala Seksi Sumber daya manusia dan Hukum, mempunyai tugas pokok melakukan pengelolaan data dan sistem informasi Sumber daya manusia; pendataan kebutuhan dan pengembangan sumber daya manusia; pengusulan rotasi, mutasi dan promosi karyawan; pengelolaan administrasi dan kesejahteraan karyawan; penerapan K3 LH; penyusunan dan penelaahan perjanjian/kontrak; pelayanan konsultasi hukum; penanganan dan pemantauan penyelesaian klaim; serta memantau, mengevaluasi dan melaporakan kegiatan pengelolaan sumber daya manusiass dan Hukum.

c. Kepala Seksi Sekretariat dan Humas, mempunyai tugas pokok melakukan pengelolaan surat menyurat, ekspedisi, dokumentasi, dan arsip dokumen perusahaan; kegiatan protokoler; administrasi dan perjalanan dinas; pengolahan berita dan informasi, menjalin komunikasi dengan media massa, masyarakat dan pemangku kepentingan (stakeholder) lainnya; pengelolaan Program Kemitraan dan Bina Lingkungan (PKBL) dalam rangka meningkatkan citra baik perusahaan; serta memantau, mengevaluasi, dan melaporkan kegiatan sekretariat dan humas.

d. Kepala Seksi Umum dan Teknologi Informasi, mempunyai tugas pokok melakukan pengelolaan kerumahtanggaan; pemeliharaan sarana dan prasarana (bangunan, kendaraan dan sarana lainnya) Divisi Regional; pengajuan usulan pengadaan sarana penyimpanan, sarana kantor, sarana lainnya dan Replacement and Rehab (RR); investarisasi dan administrasi aset tetap; pelayanan teknologi informasi, update data dan informasi pada website; pemantauan ketersediaan layanan, pemeliharaan sistem aplikasi daninfrastruktur teknologi informasi; serta memantau, mengevaluasi dan melaporkan kegiatan umum dan teknologi informasi.

e. Kepala Seksi Keuangan, mempunyai tugas pokok melakukan administrasi dan verifikasi seluruh proses penerimaan dan pengeluaran transaksi keuangan, baik untuk kegiatan operasional maupun komersial; penyelesaian tagihan/piutang usaha; pengendalian

f. Kepala Seksi Akuntansi, Manajemen Risiko dan Kepatuhan, mempunyai tugas pokok melakukan pencatatan, pengecekan, pengkoreksian dan pengarsipan seluruh transaksi keuangan; pencatatan transaksi buku tambahan terhadap akun/kodering uang muka, piutang, aset tetap, hutang dan lainnya; pengecekan, penghitungan, pemungutan, penyetoran, pelaporan dan 
penyimpanan dokumen PPN, PPh dan pajak lainnya; penyusunan laporan keuangan Divisi Regional; pengelolaan dan penerapan manajemen risiko dan kepatuhan di Divisi Regional; serta memantau, mengevaluasi dan

melaporkan kegiatan akuntansi, manajemen risiko dan kepatuhan.

\subsubsection{Hasil Pengujian Instrumen Penelitian Hasil Uji Asumsi Klasik (Uji Prasyarat Analisis Regresi Linear)}

\subsubsection{Normalitas Residual}

Normalitas residual merupakan salah satu syarat mutlak yang harus dipenuhi untuk analisis regresi linear. Pelanggaran terhadap asumsi normalitas residual akan menyebabkan hasil uji $t$ tidak dapat dijadikan landasan untuk pengambilan keputusan hasil uji hipotesis. Uji normalitas residual dilakukan melalui uji Kolmogorov-Smirnov Z. Nilai residual regresi dinyatakan memenuhi asumsi normalitas jika nilai $p$ atau nilai Asymp. Sig. lebih besar daripada 0,05 . Hasil uji normalitas disajikan pada tabel berikut.

Tabel 4.9

Ringkasan Hasil Uji Normalitas melalui Uji Kolmogorov-Smirnov Z

\begin{tabular}{|c|c|c|}
\hline & & ABS_RES \\
\hline $\begin{array}{l}\text { N } \\
\text { Normal Parameters } \\
\text { Most Extreme Differences } \\
\text { Kolmogorov-Smirnov Z } \\
\text { Asymp. Sig. (2-tailed) }\end{array}$ & $\begin{array}{l}\text { Mean } \\
\text { Std. Deviation } \\
\text { Absolute } \\
\text { Positive } \\
\text { Negative }\end{array}$ & $\begin{array}{r}60 \\
3,6597 \\
2,50087 \\
, 168 \\
, 168 \\
-, 098 \\
1,305 \\
, 066\end{array}$ \\
\hline
\end{tabular}

Tabel di atas menunjukkan nilai $p$ hasil uji Kolmogorov-Smirnov Z sebesar 0,066 atau lebih besar daripada 0,05. Karena itu dapat disimpulkan bahwa nilai residual regresi memenuhi asumsi normalitas. Oleh karena hasil uji t layak dijadikan landasan untuk pengambilan hasil uji hipotesis.

\subsubsection{Heteroskedastisitas Residual}

Heteroskedastisitas adalah suatu keadaan dimana nilai absolut residual mengalami perbedaan antar data satu dengan data lainnya atau antar satu responden ke responden lainnya. Adanya masalah heteroskedastisitas akan menyebabkan hasil uji hipotesis melalui uji $\mathrm{t}$ dan uji $\mathrm{F}$ tidak bisa dipertahankan kebenarannya. Oleh karena itu analisis regresi linear mensyaratkan tidak terjadinya masalah heteroskedastisitas. Uji heteroskedasitas dilakukan melalui uji Glejser dengan cara meregresikan variabel independen dengan nilai absolut residual. Syarat sebuah regresi dikatakan tidak mengandung masalah heteroskedastisitas adalah jika variabel independen tidak berpengaruh signifikan terhadap nilai absolut residual atau jika nilai Sig. > 0,05. Hasil uji heteroskedastisitas disajikan pada tabel berikut.

Tabel 4.10

Ringkasan Hasil Uji Heteroskedastisitas melalui Uji Glejser

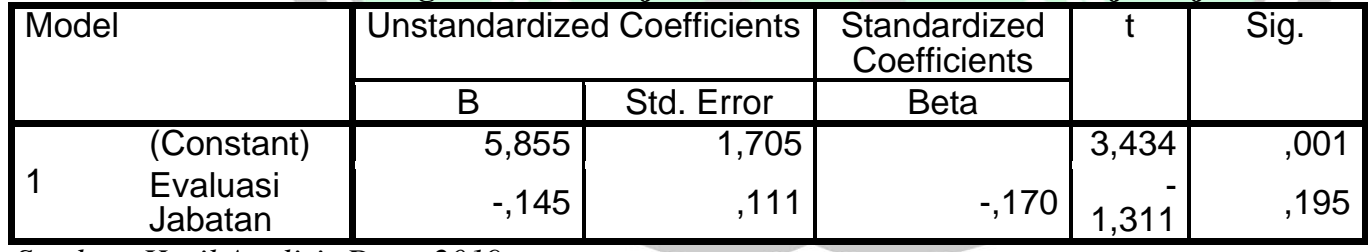

Sumber: Hasil Analisis Data, 2019

Hasil uji Glejser berdasarkan tabel di atas menunjukkan nilai sig. sebesar 0,195 atau lebih besar daripada 0,05. Maka dapat disimpulkan bahwa model regresi yang dihasilkan tidak mengandung masalah heteroskedastisitas.

\subsubsection{Hasil Analisis Regresi Linear Sederhana}

Analisis regresi linear sederhana menghasilkan tiga output utama yakni koefisien regresi, hasil uji t dan koefisien determinasi.

\subsubsection{Model Persamaan Regresi}

Model persamaan regresi merupakan sebuah persamaan untuk memprediksi (asumsi) bobot perubahan nilai variabel dependen berdasarkan perubahan variabel nilai independen. Bobot 
Tabel 4.11

Nilai Koefisien Regresi dan Nilai t-hitung

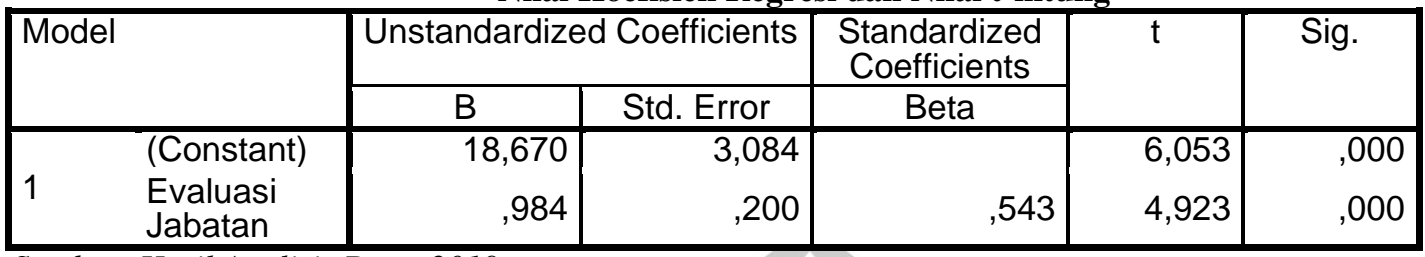

Sumber: Hasil Analisis Data, 2019

Berdasarkan tabel di atas diperoleh nilai konstantasebesar 18,670 dan koefisien regresi sebesar 0,984 , sehingga persamaan regresi yang dihasilkan adalah:

$$
\mathrm{Y}=18,670+0,984 \mathrm{X} 2
$$

Produktivitas_Kerja $=18,670+0,984($ Evaluasi

Jabatan)

Diperoleh nilai konstanta sebesar 18,670, menunjukkan bahwa jika variabel evaluasi jabatan bernilai nol atau tidak ada maka besarnya nilai variabel produktivitas kerja adalah sebesar 18,670. Koefisien regresi sebesar 0,984 menunjukkan bahwa jika variabel evaluasi jabatan menurut responden mengalami kenaikan sebesar 1 satuan variabel produktivitas kerja akan mengalami kenaikan sebesar 0,984 .

\subsubsection{Hasil Pengujian Hipotesis}

Berdasarkan tabel 4.11 diperoleh nilai t-hitung sebesar 4,923. Nilai t-tabel pada $\alpha$ : 0,05 dan $\operatorname{df}(n-2)$ adalah sebesar 2,002. Karena nilai t-hitung lebih besar daripada nilai t-tabel maka keputusan yang diambil adalah menerima Ha. Artinya evaluasi jabatan berpengaruh signifikan terhadap produktivitas kerja karyawan pada Perum Bulog Divisi Regionel Nusa Tenggara Barat. Artinya adanya peningkatan evaluasi jabatan menurut karyawan akan meningkatkan produktivitas kerja.

\subsubsection{Koefisien Determinasi $\left(R^{2}\right)$}

Koefisien determinasi yang merupakan angka persentase dari nilai $\mathrm{R}^{2}$ adalah nilai yang menunjukkan sejauhmana variasi atau perubahan nilai variabel independen dalam menjelaskan adanya perubahan nilai variabel dependen. Tabel nilai koefisien determinasi disajikan pada tabel berikut.

Tabel 4.11

Nilai Koefisien Regresi dan Nilai Koefisien Determinasi

\begin{tabular}{|l|r|r|r|r|}
\hline Model & \multicolumn{1}{|c|}{$\mathrm{R}$} & $\mathrm{R}$ Square & $\begin{array}{c}\text { Adjusted R } \\
\text { Square }\end{array}$ & $\begin{array}{c}\text { Std. Error of } \\
\text { the Estimate }\end{array}$ \\
\hline 1 &, 283 &, 295 &, 283 & 4,49638 \\
\hline
\end{tabular}

Sumber: Hasil Analisis Data, 2019

Berdasarkan tabel di atas diperoleh nilai $\mathrm{R}^{2}$ (Rsquare) sebesar 0,295 atau koefisien determinasi sebesar $29,5 \%$. Hal ini berarti bahwa perubahan nilai variabel produktivitas kerja karyawan mampu dijelaskan oleh perubahan nilai variabel evaluasi jabatan sebesar $29,5 \%$. Sedangkan sisanya sebesar $70,5 \%$ mampu dijelaskan oleh variabel residual atau variabel yang tidak dapat diprediksi (unpredicted variables).

\subsection{Pembahasan}

Hasil uji hipotesis menunjukkan nilai t-hitung $(4,923)$ lebih besar daripada t-tabel $(2,002)$. Hal ini membuktikan secara empiris bahwa evaluasi jabatan berpengaruh signifikan dan positif terhadap produktivitas kinerja karyawan pada Perum Bulog Divisi Regionel Nusa Tenggara Barat. Adanya peningkatan persepsi pegawai tentang evaluasi jabatan maka akan terjadi peningkatan produktivitas kinerja mereka.
Hasil penelitian ini sangat relevan dengan hasil penelitian yang dilakukan oleh Ida Cahaya (2017). Melalui hasil observasi dan wawancara, hasil penelitian tersebut membuktikan bahwa dalam upaya meningkatkan kinerja pegawai perlu dilakukan evaluasi secara berkala untuk setiap posisi jabatan. Begitu pula dengan penelitian yang dilakukan oleh Bobi Rachman (2017). Hasil penelitian tersebut mengungkap bahwa evaluasi jabatan berpengaruh signifikan dan positif terhadap kinerja karyawan.

Evaluasi jabatan adalah suatu proses yang bertujuan untuk menentukan nilai relative berat atau ringannya suatu pekerjaan dibandingkan pekerjaanpekerjaan dalam sebuah organisasi. Evaluasi jabatan yang baik akan sangat membantu manajemen daam meningkatkan kinerja karyawan. Menurut Peraturan Kepala Badan Kepegawaian Negara Nomor 21 Tahun 2011 tentang Pedoman Pelaksanaan Evaluasi Jabatan PNS, Evaluasi Jabatan Pegawai Negeri Sipil 
adalah suatu proses untuk menilai suatu jabatan secara sistematis dengan menggunakan kriteriakriteria yang disebut sebagai faktor jabatan terhadap informasi faktor jabatan untuk menentukan nilai jabatan dan kelas jabatan.

Peningkatan kinerja karyawan dapat terjadi bila mekanisme penempatan karyawan dalam jabatan mengacu kepada informasi hasil analisa jabatan, begitupula dengan pelaksanaan promosi dan pengembangan karyawan. Dengan kata lain karyawan yang ditempatkan dalam satu tugas atau jabatan dapat dipastikan telah memiliki abilities untuk melaksanakan pekerjaannya. Selain itu, perlakuan yang adil terhadap karyawan terutama dalam peningkatan kinerjanya dan pemberian tanggung jawab yang jelas akan menimbulkan motivasi dalam diri karyawan.

\section{KESIMPULAN DAN SARAN}

\subsection{Kesimpulan}

Berdasarkan hasil dan pembahasan hasil penelitian maka dapat disimpulkan bahwa evaluasi jabatan berpengaruh signifikan terhadap produktivitas kerja karyawan pada Perum Bulog Divisi Regionel Nusa Tenggara Barat. Artinya adanya peningkatan evaluasi jabatan menurut karyawanakan meningkatkan produktivitas kerja karyawan. Bobot pengaruh variabel evaluasi jabatan terhadap produktivitas kinerja karyawan sebesar 0,984 yang menunjukkan bahwa jika variabel evaluasi jabatan menurut responden mengalami kenaikan sebesar 1 satuan variabel produktivitas kerja akan mengalami kenaikan sebesar 0,984 .

\subsection{Saran}

Dari hasil kesimpulan di atas, penulis mencoba untuk memberikan saran sebagai berikut:

1. Dalam rangka meningkatkan kinerja aparatur maka analisis jabatan, yang dilakukan melalui jalur persyaratan jabatan dan uraian pekerjaan hendaknya diterapkan secara tepat dan benar atau harus memenuhi kualifikasi yang telah ditentukan. Hal tersebut dapat dilakukan melalui reformasi administrasi, dan menghilangkan praktek-praktek yang melanggar etika birokrasi.

2. Melakukan evaluasi terhadap Tim dan melakukan perombakan terhadap anggota tim, agar tidak terjadi perbedaan pandangan dalam memberikan penilaian yang lebih objektif.

3. Menciptakan suasana kerja yang lebih kondusif agar terjalinnya hubungan kerja yang harmonis, selaras, dan serasi diantara unit kerja, dan menghilangkan perasaan yang dapat menimbulkan kecemburuan diantara aparatur melalui pembinaan dan pengembangan kompetensi sehingga tercapai produktivitas yang optimal.

4. Penelitian ini lebih kepada pendekatan kuantitatif untuk menganalisis pengaruh evaluasi jabatan terhadap produktivitas kinerja. Oleh karena itu untuk memperdalam pemahaman tentang korelasi kedua aspek tersebut, perlu dilakukan pengkajian secara mendalam melalui pendekatan kualitatif melalui wawancara terstruktur dan mendalam

\section{DAFTAR PUSTAKA}

Arikunto, Jabar dan Abdul. 2010: 56. Prosedur Evaluasi. Jakarta: Bumi Aksara.

Ardana. 2012. Analisis dan Deskripsi Jabatan. (Teori). Jakarta: Penerbit Erlangga.

Bangun. 2012:201. Pelatihan Keterampilan Karyawan Untuk Menghasilkan Pekerjaan Yang Efekti.

2001. Untuk Meningkatkan Kinerja Karyawa dan Manajemen Sumber Daya Manausi. Jakarta: Erlangga.

Dessler. 2008. Evakuasi Jabatan. (teori dan praktek). Jakarta, Bumi Aksara.

2008. Uraian Jabatan. (Teori). Jakarta, Bumi Aksara.

Ghozali. 2005. Analisis Dengan Program SPSS. Semarang: Badan Penerbit-Undip.

Gomes, 1995. Teori dan Analisi Kinerja Karyawan. Jakarta: Bumi Aksara.

Mondy. 2018. Analisis Jabatan. Jakarta : Penerbit Erlangga.

Muchdarsyah, 2009. Produktivitas Apa dan Bagaimana. Jakarta: Bumi Aksara.

Noe. 2010. Analisis Penelitian Analisis Penilaian Kinerja.

2010. Pelatihan dan Faktor Mutu Karyawan.

Rahayu, S, Diyan Kurniawati. 2007. Pengaruh Sistem Penghargaan terhadap Kinerja Pegawai Pada Perum Bulog Devisi Regional Palu. 
Ruslan. 2008. Metode Penelitian Analisis Sensus. (Teori).

Suhaimi, R. 2017. Pengaruh Promosi Jabatan Terhadap Kinerja Karyawan Pada PT Garuda Metalindo.

Siswanto. 2002. Urain Jabatan (Job description). (Teori).

Sustrisno, 2011. Manajemen Sumber Daya Manusia. Jakarta: Kencana.

2011. Produktivitas Kerja. (Teori), Jakarta: Bumi Aksara.

2010. Indikator-Indikator Produktivitas Kerja. Jakarta, Bumi Aksara

Sumber Daya Manusia Dan Produktivitas Kerja. Bandung: Mandar Maju. 2010.

Siagian. 2011. Manajemen Sumber Daya Manusia. Jakarta: Bumi Aksara.

Sugiyono. 2013. Metode Penelitian Kuant

Bandung: Alfabeta.

2012. Metode Penelitian Populasi. Bandung: Alfabeta.

2014. Metode Penelitian Kombinasi. Bandung: Alfabeta.

2014. Metode Pengumpulan Data. Bandung: Alfabeta.

2014. Pengolahan Data. Bandung: Alfabeta.

2004. Teknik Analisis Data. Bandung: Alfabeta.

Widodo T. 2014. Pengaruh Lingkungan Kerja Budaya Organisasi Kepemimpinan Terhadap Kinerja Studi Pegawai Kecamatan Sidorejo Kota Salattiga.

Yanti, D. 2009. Manajemen Sumber Daya Manusia, Reformasi Birokarsi, dan Manajemen Pegawai Negra Sipil. Bandung: Retikaditami.

2012. Pengaruh Lingkungan Kerja Terhadap Produktivitas Kerja Karyawan Pada Perusahaan Knalopot Diesel Timbul Jaya Nguntut Tulungagung. 